\title{
PROFITABLE WASTE OIL BURNINGSYSTEM
}

\author{
R. Ramasrichandra \\ Department of Chemical Engineering, \\ Indian Institute of Petroleum and Energy, A.P, India
}

\begin{abstract}
By autonomously navigating the water's surface, Sea swarm proposes a new system for ocean-skimming andoil removal. Sea swarm uses a photovoltaic-powered conveyor belt made of a thin nanowire mesh to propel itself and collect oil. The nanomaterial, patented at MIT, can absorb up to 20 times its weight in oil. The flexible conveyor belt softly rolls over the ocean's surface, absorbing oil while deflecting water because of its hydrophobic properties

Sea swarm is meant to figure as a fleet, or "swarm" of vehicles, which communicate their location through GPS and Wi-Fi so as to make an organized system for collection that can work continuously without human support. Sea swarm works by detecting the sting of a spill and moving inward until it's removed the oil from one site before joining other vehicles that are still cleaning. The fleet uses cuttingedge nanotechnology to unravel current environmental problems while envisioning long-term solutions for the longer term. With a replacement design strategy, we will revive and preserve the standard of our oceans.
\end{abstract}

Keywords - Nanowire mesh, sea-swarm, nano-material, hydrophobic properties', GPS\&WIFI system, swarm, unravel current environment.

\section{INTRODUCTION}

Each Sea swarm robot is comprised of ahead, which is roofed by a layer of photovoltaic cells, and a nanowire-covered conveyer belt. The photovoltaic cells generate enough electricity to stay thefleet moving for several weeks and supply the energy to propel the vehicles forward. As the head moves through the water, the conveyor belt constantly rotates and sucks up pollution. The nano wire-covered belt is then compressed to get rid of the oil. As the clean part of the belt comes out of the top, it immediately begins absorbing oil, making the gathering process seamless and efficient.

This process is more streamlined than current oceanskimming technologies because the robots can operate autonomously and donot get to return to the shore for constant maintenance. As the vehicles add unison, they'll cover large areas and by communicating with one another and researchers ashore, they'll coordinate their collection efforts. Measuring just 16 feet long by seven feet wide, the fleet can access hardto-reach places like coastlines and estuaries

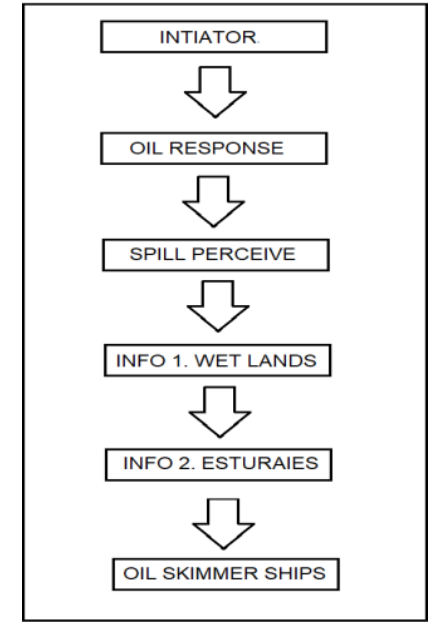

Fig.1 Proposed model of projection through various steps to carry out the output of skimmer for the spilledships

\section{NANOWIRE MESH}

Considerable uncertainty in understanding ofnano-specific attributes and relevance to biological and environmental effects

- Size matters, but it's not clear there is a brightline, e.g., at $100 \mathrm{~nm}$

- Regulatory approaches are likely to be case-by-case in the near term

- Perceptions outside of the industry and the government are critical and proactive measuresto communicate with the public are critical to successful development of nano-products the design of a back propagation neural network fractional controller is designed based on Harsdorf derivative and integral, which isintroduced to PID controller and, the tuning process for all controller parameters and order is done using Borges derivative which enhance the optimization process and fastly obtained the suitable values for reaching to desired response and finally a comparison with PIDNN that show the improvement appear on the response speed with accurate and stable behavior.

functions are minimized when compared with classical PID controllers.

In [1] author adopts three controllers a classical PID controller tuned using Ziegler-Nichols, classical PID controller tuned using ant colony optimization method and finally FOPID controller tuned using ant colony optimization for controlling the speed of a DC motor, the simulation results show the efficient behavior of FOPID in minimizing the error value between actual and desired response at steady state with minimum overshoot and settling time, in [9] a FOPID controlleris used for controlling a model of third-order (a permanent magnet synchronous motor), parameters of the controller are obtained analytically that achieves an efficient 
performance when compared with optimal FOPID and Bode shaping FOPIDcontrollers.

\section{WASTE OIL TRAY SETUP}

Each robot is comprised of a head, which is roofed by a layer of photovoltaic cells, and an oil absorbing fabric covered conveyer belt. The photovoltaic cells generate enough electricity to stay the fleet moving for several weeks and supply the energy to propel the vehicles forward.

As the top moves through the water the conveyer belt constantlyrotates and sucks up pollution. The fabric-covered belt is then compressed to get rid of the oil. because the clean a part of the belt comes out of the top it immediately begins absorbing oil, making the gathering process seamless and efficient.

This process is more streamlined than current oceanskimming technologies because the robots can operate autonomously anddon't get to return to the shore for constant maintenance.because the vehicles add unison, they will cover large areas and by communicating with one another and researchers ashore Measuring just 16 feet long by seven feet wide, the fleet can access hard to succeed in places like coastlines and estuaries.

Recent years have witnessed, many cities facing problems in waste management. Many steps have been taken on separation and recycling of wastes. Bio- degradable wastes can be used asmanure for gardens at houses. To avoid accumulation of wastes, a waste grinding dustbin, can be developed.

The wastes generated at home can be converted in manure at home itself. used one has fast dynamics and other with time delayed system then the behavior for both systems used showedthe accurate and robust response with satisfied results. an adaptive controller is proposed for controlling ferroresonance system based on FOABC, FO Lyapunov stability method is used and the update and virtual control lawsis test at each stage to achieve an enhanced behavior in controlling the ferroresonance system with effective desired response.

In [2] the design of a back propagation neural network fractional controller is designed based on Hausdorff derivative and integral, which is introduced to the controller and, the tuning process for all controller parameters and order is done using Borges derivative which enhance the optimization process and fastly obtained the suitable values for reaching to desired response and finally a comparison with PID software that show the improvement appear on the response speed with accurate and stable behavior.

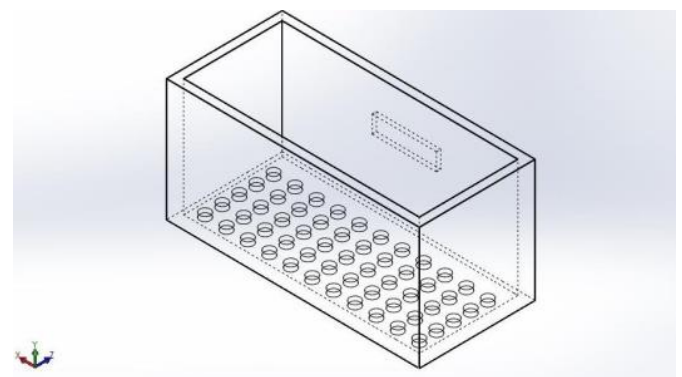

Fig2. Profitable removable tray setup based on direction of current

\section{OLDEN DAY SKIMMER SYSTEM}

Following the 2010 august greatest oil spill, 5 million barrels ofoil leaked in the GULF OF MEXICO in order to remove the oilfrom the surface of the ocean, over 800 skimmers were deployed. However, these skimmers were capable of collecting only $3 \%$ of the overall spill. The main problem arises from the challenges faced by operation flexibility and scalability

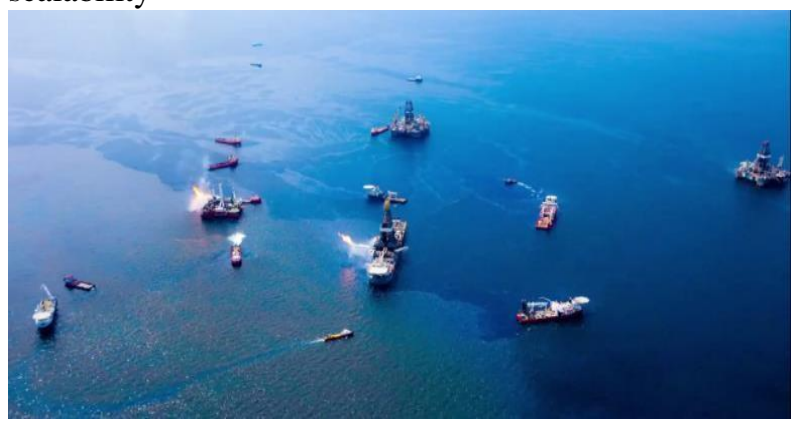

Fig3. Olden day skimmer system where 5 million of oil barrels leaked

\section{APPLICATIONS OF WASTE BURNING OIL SYSTEM}

It can be very effectively used for skimming away oil spills from the surface of oceans. The deep-water horizon rig regions can use the Sea swarm in case of accidents.

It can also be used in oil refineries near to oceans or any other industries which dispose chemicals and other wasteoils to the rivers nearby.

\section{E. ADVANTAGES}

- Small and compact

- Inexpensive

- Scalable

- Self-organizing

- Atomization compatibility

- Corral, absorb and process

- Uses renewable source-solar energy

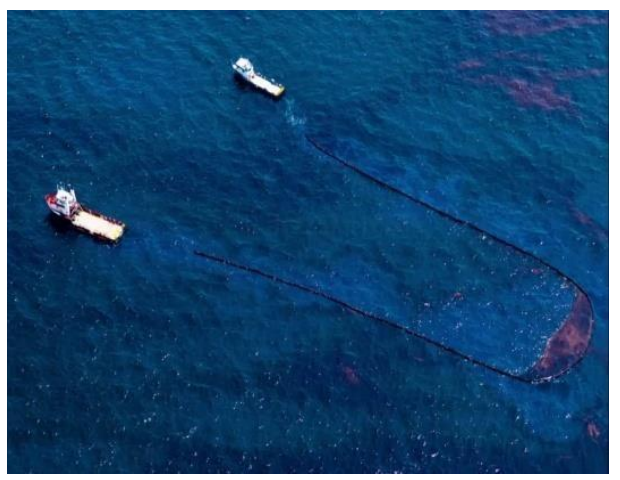

Fig4. August greatest oil spill A massive response ensuedto 
protect beaches, wetlands and estuaries from the spreading oil utilizing skimmer ships

In [3] a FOSMC is proposed with spherical robot with input saturation and a filter is adopted to achieve good control response to defeat the input saturation. The stability is tested based on Lyapunov method and then it is compared with the traditional SMC, the adjustment time become shorter and no overshoot appeared in its response.
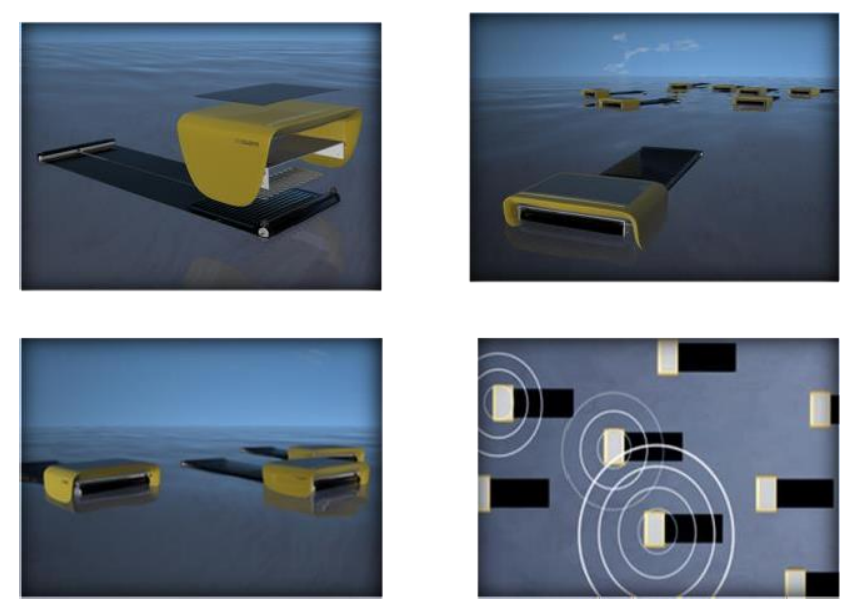

Fig5. Pictures and details of waste oil burning system signifiesThe final solution for tracer frequency

\section{CONCLUSION}

From the papers demonstrated in this study it can be seen that System controller This streamlined process shows best result than current ocean-skimming technologies because the robots can operate autonomously. They use of to the shore for constant maintenance. because the vehicles add unison, they will cover large areas and by communicating with one another and researchers the system convergence and achieve robust behavior in facing disturbances and model uncertainties.

\section{REFERENCE}

[1] El El-Khazali, Reyad. (2013). Fractional-order PI $\lambda D \mu$ controller design." Computers \& Mathematics with Applications vol.66, no.5, pp.639-646.

[2] Bhookya J., Jatoth R.K . (2019). Optimal FOPID/PID controller parameters tuning for the AVR system based on sine-cosine-algorithm. Evolutionary Intelligence vol.12, no.4, pp. 725-733.

[3] Zhou T., Xu Y. \&Wu. B. (2020). Smooth Fractional OrderSliding Mode Controller for Spherical Robots with InputSaturation. Applied

Sciences, http://dx.doi.org/10.3390/app10062117.

[4] Carolina T. Pinheiro, Margarida J. Quina, Licínio M. Gando-Ferreira. Management of waste lubricant oil in Europe: A circular economy approach. Critical Reviews inEnvironmental Science and Technology 2021, 51 (18) , 2015-

2050. https://doi.org/10.1080/10643389.2020.1771887
[5] Firoj Ali, Murari Prasad Roy, Braj Mohan Pat Pingua, Rajatendu Mukherjee, Lalit Agarwal, Pradeep Kumar Singh. Utilization of Waste Lubricant Oil in Fuel Phase of ANFO Explosives: Its Field Applications and Environmental Impact. Propellants, Explosives, Pyrotechnics 2021, https://doi.org/10.1002/prep.2021000 11

[6] Emad Benhelal, Ezzatollah Shamsaei, Muhammad Imran Rashid. Challenges against $\mathrm{CO} 2$ abatement strategies in cement industry: A review. Journal of Environmental Sciences 2021, 104 , 84-

101. https://doi.org/10.1016/j.jes.2020.11.020

[7] Carlos Sánchez-Alvarracín, Jessica Criollo-Bravo, Daniela Albuja-Arias, Fernando García-Ávila, M. Pelaez- Samaniego. Characterization of Used Lubricant Oil in a Latin-American Medium-Size City and Analysis of Options for Its Regeneration. Recycling 2021, 6 (1), 10. https://doi.org/10.3390/recycling6010010

[8] Bakhtyar K. Aziz, Muhamad A. Abdullah, Stephan Kaufhold. Kinetics of oil extraction from clay used in the lubricating oil re-refining processes and re-activation of the spent bleaching clay. Reaction Kinetics, Mechanisms and Catalysis 2021, 132 (1) , 347-

357. https://doi.org/10.1007/s11144-020-01904-7

[9] Paweł P. Włodarczyk, Barbara Włodarczyk. Applicability of Waste Engine Oil for the Direct Production of Electricity. Energies 2021, 14 (4), 1100. https://doi.org/10.3390/en 14041100

[10] Marco Tomatis, Harish Kumar Jeswani, Laurence Stamford, Adisa Azapagic. Assessing the environmental sustainability of an emerging energy technology: Solar thermal calcination for cement production. Science of The Total Environment 2020, 742 ,

140510. https://doi.org/10.1016/j.scitotenv.2020.140510

[11] Zhen Xie, Jinzhong Yang, Qifei Huang, Yufei Yang. Occurrence of heavy metals and polycyclic aromatic hydrocarbons in typical used mineral oil from China: implications for risk management. Environmental Science and Pollution Research 2020, 27 (26) , 3306533074. https://doi.org/10.1007/s11356-020-09515-4

[12] Temitayo E. Oladimeji, Kehinde M. Oguntuashe, Moses E. Emetere, Vincent E. Efeovbokhan, Olayemi A. Odunlami, Oyinlola R. Obanla. Industrial- and automotive-used lubricating oils recycling cum acidic sludge treatment. The International Journal of Advanced Manufacturing Technology 2020, 106 (9-10) , 41574167. https://doi.org/10.1007/s00170-019-04751-6

[13] Hyun-Min Hwang, Matthew J. Fiala, Terry L. Wade, Dongjoo Park. Review of pollutants in urban road dust: Part II. Organic contaminants from vehicles and roadmanagement. International Journal of Urban Sciences 2019, 23 (4), 445463. https://doi.org/10.1080/12265934.2018.1538811

[14] Cornelia Stan, Marius Toma, Cristian Andreescu, Daniel Iozsa. Comparative Study on the Regeneration of Used Motor Oil. 2019,,, 377-382. https://doi.org/10.1007/9783-319-94409-8_43

[15] A. A. Lavrinenko, N. Yu. Svechnikova, N. S. Konovnitsyna, E. A. Igumensheva, O. V. Kuklina, A. I. 
Khasanzyanova. Utilization of Bituminous Coal FlotationWastes in the Manufacture of Ceramic Brick. Solid Fuel Chemistry 2018, 52 (6) , 406410. https://doi.org/10.3103/S0361521918060083

[16] Scott A. Stout, Eric Litman, Douglas Blue. Metal concentrations in used engine oils: Relevance to site assessments of soils. Environmental

Forensics 2018, 19 (3), 191-

205. https://doi.org/10.1080/15275922.2018.1474288

[17] F. M. Adebiyi, A. F. Adeyemi, O. A. Koya. Removal of metals from flat lubricating oils using a fabricated packed-bed reactor. Petroleum Science and Technology 2018, 36 (6) , 419428. https://doi.org/10.1080/10916466.2018.1425719

[18] James G. Speight, Nour Shafik El-Gendy. Refinery Products and By-Products. 2018,, $41-$ 68. https://doi.org/10.1016/B978-0-12-805151-1.000023

[19] C.T. Pinheiro, R.F. Pais, A.G.M. Ferreira, M.J.

Quina, L.M. Gando-Ferreira. Measurement and correlation of thermophysical properties of waste lubricant oil. The Journal of Chemical Thermodynamics 2018, 116,137 -

146. https://doi.org/10.1016/j.jct.2017.08.039

[20] Ksenia Yu Vershinina, Genii V. Kuznetsov, Pavel A. Strizhak. Sawdust as ignition intensifier of coal water slurries containing petrochemicals. Energy 2017, 140 , 69-77. https://doi.org/10.1016/j.energy.2017.08.108

[21] Deepak Rajagopal, Caroline Vanderghem, Heather L. MacLean. Life Cycle Assessment for Economists. AnnualReview of Resource Economics 2017, 9 (1), 361381. https://doi.org/10.1146/annurev-resource-100815095513

[22] Ján Cvengroš, Tibor Liptaj, Nad’a Prónayová. Study of polyaromatic hydrocarbons in current used motor oils. International Journal Of Petrochemical Science \& Engineering 2017, 2 https://doi.org/10.15406/ipcse.201 7.02.00060

[23] A. F. Adeyemi, F. M. Adebiyi, O. A. Koya. Evaluation ofphysico-chemical properties of re-refined lubricating oils obtained from fabricated packed bed reactor. Petroleum Science and Technology 2017, 35 (16) , 17121723. https://doi.org/10.1080/10916466.2017.1359624

[24] Maria Oliveira, Alessandra Magrini. Life Cycle Assessment of Lubricant Oil Plastic Containers inBrazil. Sustainability 2017, 9 (4),

576. https://doi.org/10.3390/su9040576

[25] K. Yu. Vershinina, G. V. Kuznetsov, P. A.

Strizhak. Characteristics of the ignition of organic coalwater fuels for boiler installations. Solid Fuel Chemistry 2017, 51 (2), 95-

100. https://doi.org/10.3103/S0361521917020112

[26] K. Yu. Vershinina, D. O. Glushkov, P. A. Strizhak. Ignition of droplets of coal-water-oil mixtures based on coke and semicoke. Coke and Chemistry 2017, 60 (1), 28 -

36. https://doi.org/10.3103/S1068364X17010082

[27] Roland Geyer, Brandon Kuczenski, Trevor Zink, Ashley Henderson. Common Misconceptions about
Recycling. Journal of Industrial Ecology 2016, 20 (5), 1010-1017. https://doi.org/10.1111/jiec.12355

[28] Kang Zhang, Li'e Jin, Qing Cao. Evaluation of modified used engine oil acting as a dispersant for concentrated coal-water slurry. Fuel 2016, 175 , 202209. https://doi.org/10.1016/j.fuel.2016.02.026

[29] Barbara J. Parry. Oil Recycling. 2016,, 116.

https://doi.org/10.1002/0471238961.15091202050311.a 01. pub3

[30] Stephen F. Hamilton, David L. Sunding. Optimal Recycling Policy for Used Lubricating Oil: The Case of California's Used Oil Management Policy. Environmentaland Resource Economics 2015, 62 (1) , 317. https://doi.org/10.1007/s10640-014-9812-x

[31] Esmail Aflaki, Alborz Hajiannia. Stabilization of sand dunes with oil residue: Application to civil engineering construction and environmental implications. Journal of Central South University 2015, 22 (8), 30593068. https://doi.org/10.1007/s11771-015-2842-X

[32] Q. M. Langfitt, L. M. Haselbach. Life Cycle Assessment Synthesis for a Volume of Lubricating Oil in Marine Applications. 2015,,, 188-

199. https://doi.org/10.1061/9780784479285.016

[33] NURIA GARCIA-MANCHA, DANIEL PUYOL, VICTOR MONSALVO, HAYFA RAJHI, ANGEL MOHEDANOA, JUAN

RODRIGUEZ. Anaerobic Treatment of Wastewater fromUsed Industrial Oil Recovery. 2015,,, 325. https://doi.org/10.1201/b18617-3

[34] Wasiu Olalekan Akintunde, Ojo A. Olugbenga, Ogundipe

O. Olufemi. Some Adverse Effects of Used Engine Oil (Common Waste Pollutant) On Reproduction of Male Sprague Dawley Rats. Open Access Macedonian Journal of Medical Sciences 2015, 3 (1), 46-

51. https://doi.org/10.3889/oamjms.2015.035

[35] . LUBRICATING OIL. 2015,,, 222243. https://doi.org/10.1002/9781118986370.ch13

[36] Xingzhong Yuan, Lijian Leng, Huajun Huang, Xiaohong Chen, Hou Wang, Zhihua Xiao, Yunbo Zhai, Hongmei Chen, Guangming Zeng. Speciation and environmental risk assessment of heavy metal in bio-oil from liquefaction/pyrolysis of sewage sludge. Chemosphere 2015, 120,645 652. https://doi.org/10.1016/j.chemosphere.2014.10.010

[37] Larry D. Claxton. The history, genotoxicity, and carcinogenicity of carbon-based fuels and their emissions. Part 3: Diesel and gasoline. Mutation Research/Reviews inMutation Research 2015, 763, 3085. https://doi.org/10.1016/j.mrrev.2014.09.002

[38] . Rerefining and Recycling of Used Lubricating Oil. 2014,, 299-

307. https://doi.org/10.1002/9781118907948.ch18

[39] V Kapustina, J Havukainen, T Virkki-Hatakka, M Horttanainen. System analysis of waste oil management inFinland. Waste Management \& Research: The Journal fora Sustainable Circular Economy 2014, 32 (4) , 297303. https://doi.org/10.1177/0734242X14523663

[40] Antonina Kupareva, Päivi Mäki-Arvela, Dmitry Yu. 
Murzin. Technology for rerefining used lube oils applied in Europe: a review. Journal of Chemical Technology \& Biotechnology 2013, 88 (10), 17801793. https://doi.org/10.1002/jctb.4137

[41] Matthew J. Eckelman, Marian R. Chertow. Life cycle energy and environmental benefits of a US industrial symbiosis. The International Journal of Life Cycle Assessment 2013, 18 (8), 1524-

1532. https://doi.org/10.1007/s11367-013-0601-5

[42] Ihsan Hamawand, Talal Yusaf, Sardasht Rafat. Recyclingof Waste Engine Oils Using a New Washing Agent. Energies 2013, 6 (2), 10231049. https://doi.org/10.3390/en6021023

[43] Ana Pires, Graça Martinho. Life cycle assessment of a waste lubricant oil management system. The InternationalJournal of Life Cycle Assessment 2013, 18 (1) , 102- 112. https://doi.org/10.1007/s11367-012$0455-2$

[44] Nuria Garcia-Mancha, Daniel Puyol, Victor M. Monsalvo, Hayfa Rajhi, Angel F. Mohedano, Juan J. Rodriguez. Anaerobic treatment of wastewater fromused industrial oil recovery. Journal of Chemical Technology \& Biotechnology 2012, 87 (9) , 1320- 1328. https://doi.org/10.1002/jctb.3753

[45] Georgios Gaidajis, Komninos Angelakoglou, Pantelis N. Botsaris, Faidra Filippidou. Analysis of the recycling potential of used automotive oil filters using the Life Cycle Assessment approach. Resources, Conservation and Recycling 2011, 55 (11), 986-

994. https://doi.org/10.1016/j.resconrec.2011.05.008

[46] Zenon Pawlak, Wieslaw Urbaniak, Tadeusz

Kaldonski, Michal Styp-Rekowski. Energy conservation through recycling of used oil. Ecological

Engineering 2010, 36 (12) , 1761-

1764. https://doi.org/10.1016/j.ecoleng.2010.08.007

[47] Jeffrey Morris, H. Scott Matthews. Development of a Consumer Environmental Index and Results for Washington State Consumers. Journal of Industrial Ecology 2010, 14 (3) , 399-

421. https://doi.org/10.1111/j.1530-9290.2010.00246.x

[48] Zhongping Deng, Lisa A. Dailey, Joleen Soukup, Jacqueline Stonehuerner, Judy D.Richards, Kimberly D. Callaghan, Funmei

Yang, Andrew J. Ghio. Zinc transport by respiratory epithelial cells and interaction with iron homeostasis. BioMetals 2009, 22 (5) , 803-

815. https://doi.org/10.1007/s10534-009-9227-2

[49] Eric Masanet, Jayant Sathaye. Challenges and opportunities in accounting for non-energy use $\mathrm{CO} 2$ emissions: an editorial comment. Climatic

Change 2009, 95 (3-4) , 395-

403. https://doi.org/10.1007/s10584-009-9636-9

[50] W. David Conn. Applying environmental policy instruments to used oil. Journal of Environmental Planning and Management 2009, 52 (4) , 457- 475. https://doi.org/10.1080/09640560902868181

[51] Mikhail V Chester, Arpad Horvath. Environmental assessment of passenger transportation should include infrastructure and supply chains. Environmental Research Letters 2009, 4 (2),
024008. https://doi.org/10.1088/1748-9326/4/2/024008

[52] Dennis Brinkman, Barbara Parry. Used Oil Recycling and Environmental Considerations. 2008,, 10-1-10- 14. https://doi.org/10.1201/9781420089363.ch10

[53] D. M. Murphy, P. K. Hudson, D. J. Cziczo, S. Gallavardin, K. D. Froyd, M. V. Johnston, A. M. Middlebrook, M. S. Reinard, D. S. Thomson, T. Thornberry, A. S. Wexler. Distribution of lead in single atmospheric particles. Atmospheric Chemistry and Physics 2007, 7 (12) , 3195-

3210. https://doi.org/10.5194/acp-7-3195-2007

[54] R. Navia, B. Rivela, K.E. Lorber, R. Méndez. Recycling contaminated soil as alternative raw material in cement facilities: Life cycle assessment. Resources, Conservation and Recycling 2006, 48 (4), 339356. https://doi.org/10.1016/j.resconrec.2006.01.007

[55] Martina Solenská, Karol Mičieta, Miroslav Mišík. Plant Bioassays for an in Situ Monitoring of Air Near an Industrial Area and a Municipal Solid Waste - ŽILINA (SLOVAKIA). Environmental Monitoring and Assessment 2006, 115 (1-3), 499508. https://doi.org/10.1007/s10661-006-7240-2

[56] Dennis Brinkman, Barbara Parry. Used Oil Recycling and Environmental Considerations. 2006,,, 37-1-37- 14. https://doi.org/10.1201/9781420003840.ch37 